\title{
Identification and biochemical characterization of resistance against downy mildew in snapmelon
}

\author{
SITA KHANAL*, PARVINDER SINGH SEKHON and ASTHA \\ Department of Plant Pathology, Punjab Agricultural University, Ludhiana 141 004, Punjab, India
}

Received: 4 July 2017/ Accepted: 14 August 2017/ Published online: 31 August 2017

(C) Indian Phytopathological Society 2017

\begin{abstract}
Snapmelon downy mildew, an important foliar disease caused by Pseudoperonospora cubensis is an obligate parasite, which can survive and reproduce on living host tissue, causing significant yield losses. Forty six accessions of snapmelon were screened against $P$. cubensis in the cropping season 2015 and 2016. Plants were inoculated at optimum level of sporangial suspension $\left(4.0 \times 10^{4}\right.$ sporangia per $\left.\mathrm{ml}\right)$ to create downy mildew. Out of forty six accessions, three were resistant having incidence in the range of 20-30 per cent and rest were moderately resistant, moderately susceptible, susceptible and highly susceptible. Significant mean maximum disease severity was observed in snapmelon accession SM 2013-7 and minimum in accession MC 2013-4. For further confirmation, biochemical studies of various defense enzymes were carried out in resistant accessions and compared with susceptible. The data pertaining to the activity of peroxidase, catalase, phenylalanine ammonia lyase and total phenols revealed significant differences $(p=0.05)$ among the different accessions of snapmelon showing different reactions against $P$. cubensis. Higher activity of all those antioxidant enzymes were observed in resistant, followed by moderately resistant whereas activity gradually declined among susceptible and highly susceptible accessions. Negative values of Pearson's correlation coefficient were obtained between antioxidant enzyme activity and disease development suggesting possible involvement of these enzymes in imparting resistance against downy mildew in snapmelon.
\end{abstract}

Keywords: Disease severity, enzymes, Pseudoperonospora cubensis, Cucumis melo L. Var. momordica

The production of cucurbits is severely affected by the occurrence of cucurbits downy mildew caused by Pseudoperonospora cubensis. The disease is prevalent in all cucurbits growing areas and has potential to destroy the crop within a short period of time causing both qualitative and quantitative losses in the crop yield (Lebeda and Cohen, 2011). Olczak-Woltman et al. (2011) observed that downy mildew is the most destructive disease of muskmelon. Depending on the light intensity, temperature, humidity and inoculums concentration, the disease symptoms become visible 4-12 days after infection.

The favorable temperature for germination lies between $10-20^{\circ} \mathrm{C}$, whereas the germination rate retard with warmer temperatures (above $30^{\circ} \mathrm{C}$ ) (Lebeda and Cohen, 2011). Research on disease resistance has been conducted around the world with a major objective to enhance the level of resistance against downy mildew. The highest level of sources of resistance to downy mildew originates from the far east. Wild melon (Cucumis melo var. callosus) is a reservoir for resistance genes against downy mildew (Roy et al., 2011).

Vashisht et al. (2012) developed a downy mildew resistant inbred line MM-31 which will be useful for developing downy mildew cultivars/hybrids in muskmelon.

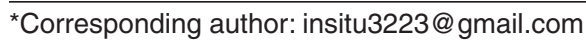

Kozik and Paris (2016) observed the broad resistance pattern in accession PI 315410 of C. melo, which was completely resistant to five isolates of $P$. cubensis. After a pathogen invasion there is activation of variety of plant defense responses via signal transduction cascade activation, which involves oxidative burst, reinforcement of cell walls, hypersensitive response and production of phytoalexins (Balmer et al., 2013). Recently, Kumar (2015) and Dhkal et al. (2016) have reported significant role of some antioxidants in imparting resistance in some lines of maize crop to a bacterial stalk rot (Dickeya zeae) and bacterial leaf streak pathogen respectively. However, there is no information available regarding the role of antioxidant enzymes in modulating resistance to downy mildew. Hence the objective of the current studies was to determine the role of four antioxidant enzymes in imparting resistance to downy mildew pathogen in different accessions of snapmelon showing different reaction against $P$. cubensis.

\section{MATERIALS AND METHODS}

\section{Establishment of Crop}

Forty-six accessions of snapmelon were sown at the end of August 2015 and 2016 during the cropping season in the open field conditions at Research Farm of Department of Plant Pathology and Bio-chemistry 
laboratory of College of Basic Science and Humanities at Punjab Agricultural University, Ludhiana during 201516. Two seeds of each accession were sown in polythene bags of $15 \times 10 \mathrm{~cm}$ size and 100 gauge thickness. Five plants per accessions were sown in each replicated blocks.

\section{Preparation of sporangial suspension}

Fresh sporulation of $P$. cubensis was taken and sporangial suspension $\left(4.0 \times 10^{4}\right.$ per $\left.\mathrm{ml}\right)$ was made in double distilled water for inoculation in the field. Humidity was maintained through artificial spraying of water within 3 hours interval starting from $8 \mathrm{am}, 11 \mathrm{am}, 2 \mathrm{pm}$ and $5 \mathrm{pm}$ for 3 days. Symptoms as yellow patches started appearing on the $4^{\text {th }}$ day after inoculation.

\section{Determination of disease incidence and severity}

After one week of pathogen inoculation, observations on disease incidence and severity were recorded. Disease intensity was recorded by visual observation using 0-5 scale adopted by Thind et al. (1989) whereas disease severity is calculated by using following formula:

Percent disease intensity $(\mathrm{PDI})=\frac{\Sigma(\mathrm{n} \times \mathrm{v})}{\mathrm{N} \times \mathrm{S}} \times 100$

Where,

$\Sigma=$ Summation, $\mathrm{n}=$ Number of leaves in each category, $\mathrm{N}=$ Number of leaves examined, $\mathrm{S}=$ Maximum numerical value and $v=$ Numerical value of each category

\section{Multiplication of $\boldsymbol{P}$. cubensis}

The inoculum of $P$. cubensis was multiplied by detached leaf technique (Thind et al., 1989). Detached leaves of snapmelon were thoroughly washed with tap water, then air dried and placed in plastic trays measuring $45 \times 50$ $\mathrm{cm}$ lined with moist blotting paper. The leaves were inoculated with optimum level of sporangial suspension $\left(4.0 \times 10^{4}\right)$ sporangia per $\mathrm{ml}$ which was obtained from natural disease leaves. Hand atomizer was used to spray the leaves kept in tray and were incubated in growth chamber at temperature of $20-22^{\circ} \mathrm{C}$, photoperiod of 12 hours was provided with fluorescent tubes. Profuse growth of whitish mycelium with sporangia and sporangiophores was visible after 10 days of incubation.

\section{Sampling of tissue for estimation of defense related enzymes}

Healthy tissues adjacent to the inoculating point or the advancing lesions on the inoculated leaves were sampled separately at 7, 14 and 21 days after inoculation. Tissue were sampled from at least three leaves after pathogen inoculation. The uninoculated leaves were used as control. The leaf tissue was immediately put into labelled polyethylene bags and placed in the ice-box and transported to laboratory.

\section{Extraction and estimation of enzymes}

One hundred $\mathrm{mg}$ of leaf tissue from each plant was extracted in a pre-chilled pestle and mortar with $2 \mathrm{ml}$ $0.1 \mathrm{M}$ sodium phosphate buffer $(\mathrm{pH} 7.5)$ containing 10 $\mathrm{mM} 2$-mercaptoethanol in the presence of $1 \%$ polyvinylpyrrolidone (PVP). The homogenate was centrifuged at $13,000 \mathrm{~g}$ at $4^{\circ} \mathrm{C}$ for $30 \mathrm{~min}$ and clear supernatant was used for estimating enzymes viz. peroxidase, catalase and phenylalanine ammonia lyase. However, for the calculation total phenols, leaf tissue were firstly oven dried and boiled in methalon and further estimation takes places.

\section{Peroxidase}

The enzyme was assayed by following the appearance of brown colouration in the presence of hydrogen peroxidase. Reaction mixture in a dry test tube was taken that consists of $3.5 \mathrm{ml}$ of $50 \mathrm{mM}$ phosphate buffer $(\mathrm{pH}$ 6.5), $0.2 \mathrm{ml}$ of enzyme extract and $0.1 \mathrm{ml}$ of O-Dianisidine solution. The mixture was brought to $30^{\circ} \mathrm{C}$ in a constant temperature water bath and $0.1 \mathrm{ml}$ of $6 \% \mathrm{H}_{2} \mathrm{O}_{2}$ was added to it. This solution was then transferred to spectrophotometric cuvette and the absorbance was recorded at $430 \mathrm{~nm}$ for $3 \mathrm{~min}$ at $30 \mathrm{sec}$ intervals. The enzyme activity was expressed as $\mathrm{A} / \mathrm{min} / \mathrm{g}$ fresh wt. of tissue (Clariborne and Fridovich, 1979).

\section{Catalases}

The procedure was same as peroxidase but substrate used is hydrogen-peroxidase and spectrome which is visible is $240 \mathrm{~nm} . \mathrm{H}_{2} \mathrm{O}_{2}$ shows an absorption maximum at $240 \mathrm{~nm}$ in the presence of ultraviolet range. The decomposition of $\mathrm{H}_{2} \mathrm{O}_{2}$ can be followed directly by observing the decrease in absorbance at $240 \mathrm{~nm}$ as a measure of catalase activity. $\mathrm{H}_{2} \mathrm{O}_{2}$ shows an absorption maximum at $240 \mathrm{~nm}$ in the presence of ultraviolet range. The decomposition of $\mathrm{H}_{2} \mathrm{O}_{2}$ can be followed directly by observing the decrease in absorbance at $240 \mathrm{~nm}$ as a measure of catalase activity (Aebi, 1983).

\section{Phenylalanine ammonia lyase}

The enzyme was assayed by following the appearance of trans-cinnamic acid resulting from deamination of $L$ phenylalanine. The reaction mixture containing $2.5 \mathrm{ml}$ of $0.03 \mathrm{M}$ phenylalanine in $0.05 \mathrm{M}$ sodium borate buffer (pH8.8) and $0.1 \mathrm{ml}$ of enzyme extract was incubated at $37^{\circ} \mathrm{C}$ for $1 \mathrm{~h}$. The reaction was terminated by addition of $0.3 \mathrm{ml}$ of $5 \mathrm{~N}$ hydrochloric acid. The absorbance was recorded at $290 \mathrm{~nm}$ against water blank. A reaction mixture in which the reaction was stopped at time zero served as a control. The concentration of trans-cinnamic acid was read from the standard curve prepared by using trans-cinnamic acid in the range of 5-40 $\mu \mathrm{g}$. The enzyme activity was expressed as $\mu \mathrm{g}$ t- cinnamic acid produced $\min ^{-1} \mathrm{~g}^{-1}$ fresh weight (Burrell and Rees, 1974).

\section{Total phenols}

Four gm of fresh weight of tissue was first oven dried at $60^{\circ} \mathrm{C}$ for $4-5$ hours. $0.1 \mathrm{gm}$ of dried leave was weighted 
and boiled in $10 \mathrm{ml}$ of methanol. Methanolic extract $(0.5$ $\mathrm{ml}$ ) was evaporated to dryness and the residue was dissolved in $6.5 \mathrm{ml}$ of distilled water. $0.5 \mathrm{ml}$ of Folin-phenol reagent was added and shaken thoroughly. After $5 \mathrm{~min}$, $1 \mathrm{ml}$ of saturated solution of $\mathrm{Na}_{2} \mathrm{CO}_{3}$ was added. After $1 \mathrm{~h}$, the absorbance was read with blue colour in a spectrophotometer at $760 \mathrm{~nm}$ against the blank. The blank was prepared from water and reagents only. The total phenols concentration was determined from standard curve prepared by using gallic acid (10-50 $\mu \mathrm{g})$. The enzyme activity was expressed as $\mu \mathrm{g} / \mathrm{gm}$ of dry weigh (Swain and Hillis, 1959).

\section{RESULT AND DISCUSSION}

The evaluation of 46 snapmelon accessions against $P$. cubensis, conducted in the month of August 2015 and 2016 under artificial epiphytotic conditions, revealed differential response to the disease. The disease severity, irrespective of years, varied from 22.4 to 100 per cent. Out of 46 accessions; eleven accessions gave highly susceptible reaction against $P$. cubensis in which SM 2013-7 showed highest per cent disease severity $>90$. Twelve accessions showed susceptible reaction with per cent disease severity between $70-90 \%$. Sixteen were moderately susceptible with per cent disease severity in range of 50 to $70 \%$, whereas four accessions showed moderately resistant reaction with per cent disease severity in range of $30-50 \%$ and three accessions showed resistance reaction with per cent severity in range of 10$30 \%$ (Table 1).

The role of peroxidases, as a group of pathogenesisrelated (PR) proteins which are involved in lignin production in phenyl-propanoid pathway, in the interaction of snapmelon accessions with $P$. cubensis has been investigated. Activity of Peroxidase was significantly higher in resistant accessions of snapmelon as compared to susceptible and highly susceptible accessions. Activity was higher after 7 days of $P$. cubensis inoculation followed by 14 and 21 days after challenge inoculation (Fig. 1). Mean peroxidase activity was highest in resistant accession of snapmelon MC 2013-14. However, activity declined in highly susceptible accessions SM 2013-13 of snapmelon with (6.33 $\Delta \mathrm{A} / \mathrm{min} / \mathrm{g} \mathrm{FW})$. Thus peroxidase activity remained higher till 14 days after the challenge inoculation of $P$. cubensis. Similar result was obtained by Reuveni et al. (1992) while estimating peroxidase activity in muskmelon to Pseudoperonospora cubensis where he found that the peroxidase activity was lower in highly susceptible line, intermediate in the susceptible and high in resistant cultivars. Taheri and Tarighi (2012) reported that more peroxidase activity was found in partially resistant cultivar of tomato as compared to susceptible cultivar, their findings suggest the involvement of peroxidase in defense responses of tomato plants against $R$. solani as a destructive pathogen.

Catalase activity (CAT) is essential for the removal of the potentially toxic hydrogen peroxide produced under various stress conditions and then for the avoidance of oxidative stress related damage (Willekens et al., 1995).
Table 1. Screening of snapmelon accessions against $P$. cubensis under artificial epiphytotic conditions during 2015-16

\begin{tabular}{|c|c|c|c|c|}
\hline \multirow[t]{2}{*}{ Accessions } & \multicolumn{2}{|c|}{ Per cent Disease Index } & \multirow[t]{2}{*}{ Mean } & \multirow[t]{2}{*}{ Reaction } \\
\hline & (2015) & $(2016)$ & & \\
\hline Pushpa-1 & 66.2 & 75.6 & 70.9 & $\mathrm{~S}$ \\
\hline SM 2014-5 & 61.4 & 76.3 & 68.85 & MS \\
\hline SM 2014-7 & 35.5 & 70.0 & 52.75 & MS \\
\hline SM 2014-15 & 52.6 & 78.7 & 65.65 & MS \\
\hline MC 2012-2 & 63.3 & 60.3 & 61.8 & MS \\
\hline MC 2012-6 & 50.2 & 79.0 & 64.6 & MS \\
\hline SM 2011-1 & 47.5 & 50.5 & 49.01 & MR \\
\hline MC 2012-1 & 45.9 & 40.4 & 43.15 & MR \\
\hline SM 2015-3 & 74.1 & 80.9 & 77.5 & $S$ \\
\hline SM 2012-9 & 67.0 & 100 & 83.5 & $S$ \\
\hline MC 2013-2 & 44.3 & 80.7 & 62.5 & MS \\
\hline MC 2011-11 & 59.4 & 76.2 & 67.8 & MS \\
\hline SM 2013-2 & 85.1 & 95.9 & 90.5 & $\mathrm{HS}$ \\
\hline MC 2013-4 & 22.4 & 31.21 & 26.6 & $\mathrm{R}$ \\
\hline IC 320165 & 53.6 & 75.2 & 64.4 & MS \\
\hline IC 274034 & 45.4 & 35.6 & 40.5 & MR \\
\hline MC 2012-1 & 43.9 & 71.4 & 57.65 & MS \\
\hline MC 2012-8 & 42.8 & 78.7 & 60.75 & MS \\
\hline MC 2012-5 & 48.7 & 50.8 & 49.75 & MR \\
\hline SM 2015-2 & 86.9 & 90.3 & 88.6 & $S$ \\
\hline MC 2012-12 & 60.0 & 75.7 & 67.85 & MS \\
\hline MC 2013-1 & 89.2 & 72.6 & 80.9 & $S$ \\
\hline SM 2013-3 & 92.2 & 93.1 & 92.65 & $\mathrm{HS}$ \\
\hline SM 2014-1 & 62.5 & 80.0 & 71.25 & S \\
\hline IC 267364 & 93.0 & 93.9 & 93.4 & $\mathrm{HS}$ \\
\hline WM -12 & 40.4 & 45.2 & 42.8 & MR \\
\hline WM-12508 & 80.9 & 83.7 & 82.3 & S \\
\hline IC 267378 & 90.4 & 93.3 & 92.5 & HS \\
\hline MC 2012-6 & 47.6 & 80.3 & 63.95 & MS \\
\hline SM 2012-7 & 79.3 & 82.0 & 80.65 & $S$ \\
\hline SM 2014-16 & 44.9 & 85.5 & 65.2 & MS \\
\hline SM 2015-1 & 16.0 & 40.0 & 28 & $\mathrm{R}$ \\
\hline SM 2012-18 & 42.1 & 90.9 & 66.5 & MS \\
\hline SM 2013-12 & 74.4 & 95.6 & 85 & $S$ \\
\hline MC 2013-16 & 24.9 & 35.1 & 30.0 & $\mathrm{R}$ \\
\hline MC 2013-8 & 96.7 & 95.3 & 96 & $\mathrm{HS}$ \\
\hline SM 2013-5 & 92.9 & 88.9 & 90.9 & HS \\
\hline SM 2013/14 & 92.1 & 95.5 & 93.8 & $\mathrm{HS}$ \\
\hline SM 2014-17 & 49.0 & 70.4 & 59.7 & MS \\
\hline MC 2013-17 & 47.3 & 75.8 & 61.55 & MS \\
\hline IC 32165 & 86.1 & 95.7 & 90.9 & HS \\
\hline MC 2013-11 & 55.4 & 70.6 & 63 & MS \\
\hline SM 2013-9 & 76.6 & 95.3 & 85.95 & $S$ \\
\hline SM 2013-7 & 92.5 & 95.9 & 94.2 & HS \\
\hline MC 2013-15 & 94.7 & 90.1 & 92.4 & $\mathrm{HS}$ \\
\hline SM 2013-13 & 91.3 & 95.9 & 93.6 & HS \\
\hline
\end{tabular}




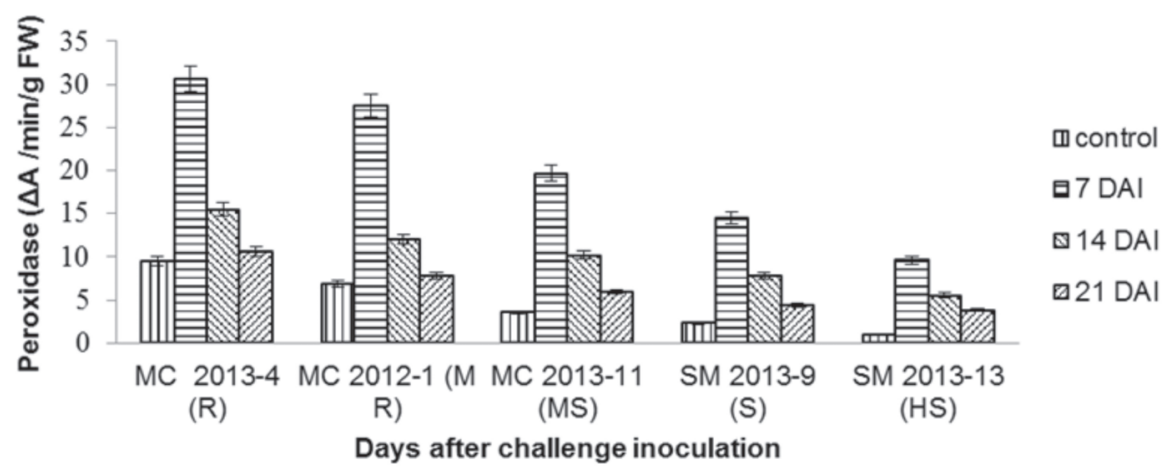

Fig. 1. Activity of peroxidase in snapmelon showing varied reaction pattern against $P$. cubensis at different days of challenge inoculation

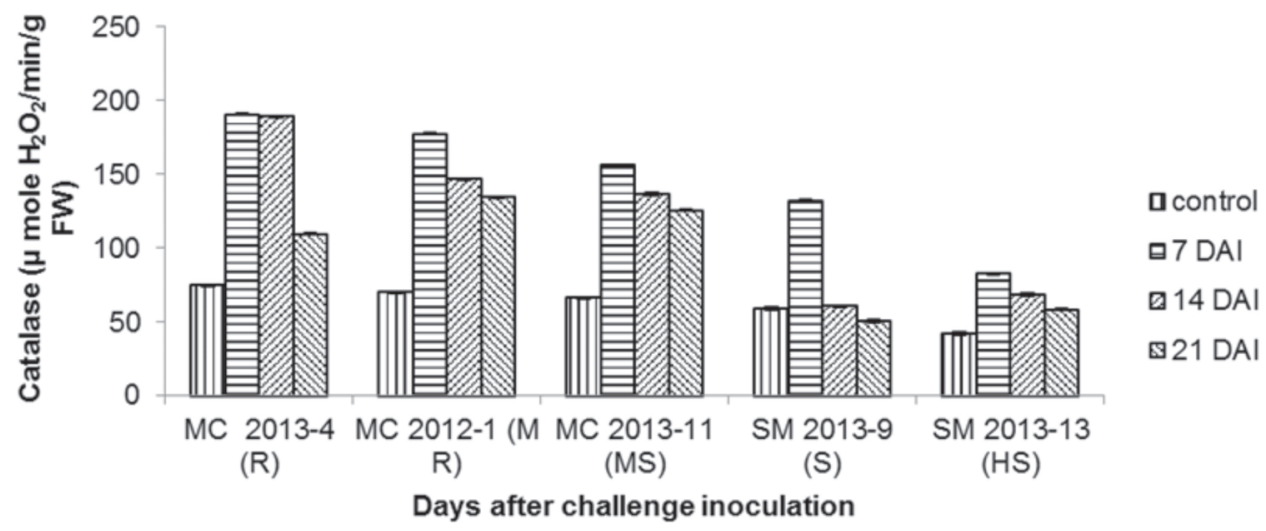

Fig. 2. Activity of catalase in snapmelon showing varied reaction pattern against $P$. cubensis at different days of challenge inoculation

Statistically significant difference in catalases activity was observed in snapmelon accessions showing different response against $P$. cubensis. CAT activity was significantly higher in resistant accession of snapmelon MC 2013-14 i.e. 159.88 ( $\mu$ mole $\mathrm{H}_{2} \mathrm{O}_{2}$ decomposed/min/ g FW). However, CAT activity declined among moderately susceptible and susceptible accessions thereby becoming minimum in highly susceptible accession (Fig. 2). Dhkal et al. (2016) reported higher catalase activity in moderately resistant varieties of maize as compared to susceptible against bacterial leaf streak in maize.

Phenylalanine ammonia lyase (PAL) is an inducible enzyme that responds to both biotic and abiotic stresses such as pathogens, UV irradiation, and low temperature (MacDonald and D'Cunha, 2007). PAL plays an important role in plant defense as it is involved in the biosynthesis of salicylic acid (SA), an essential signal involved in plant systemic resistance (Chaman et al., 2003). Statistically significant difference in PAL activity was recorded in different accessions of snapmelon showing different reaction against $P$. cubensis. The resistant accession of snapmelon showed highest mean PAL activity (6.95 units $\mu \mathrm{g}$ t-cinnamic acid $\mathrm{min}^{-1} \mathrm{~g}^{-1}$ fresh weight) than moderately susceptible (6.01 units $\mu \mathrm{g} \mathrm{t-cinnamic} \mathrm{acid} \mathrm{min}^{-1} \mathrm{~g}^{-1}$ fresh weight) and highly susceptible accession (3.85 units $\mu \mathrm{g}$ $\mathrm{t}$-cinnamic acid $\mathrm{min}^{-1} \mathrm{~g}^{-1}$ fresh weight). PAL activity peaked at 7 days after inoculation and in other PAL activity declines at 14 and 21 days after inoculation (Fig. 3). The present results are also in accordance with Katoch (2005) that showed, increase in the PAL activity on pea plants after the inoculation with E. polygoni. Raju et al. (2008) observed higher levels of PAL in roots and shoots of resistant cultivar than that of susceptible cultivar of chickpea (Cicer arietinum L.) on inoculation with pathogen (Fusarium oxysporum f. sp. ciceri). Similarly, Dhkal et al. (2016), where maximum PAL activity was observed in case of moderately resistant cultivar of maize against a isolate of Acidovorax avenae subsp. avenae as compared to highly susceptible cultivar.

Phenolic compounds are some among the most influential and widely distributed secondary products in plants. Phenolic content was higher in resistant leaves than that of the susceptible leaves. Mean maximum phenolic content was observed in resistant accessions of snapmelon (1.44 $\Delta \mathrm{A} / \mathrm{min} / \mathrm{g} \mathrm{DW}$ ) (Table 2). Phenols play an important role in host pathogen interaction, disease development and defense reaction of infected plants (Jabeen et al., 2009). Similarly, Gupta (2001) has reported higher phenolic contents in leaves and roots of resistant pearl millet than susceptible varieties.

During this study it was found that, enzyme activity at 7 days after pathogen inoculation was negatively correlated with disease development after 21 days of pathogen inoculation (Table 3). Sharma et al. (2012) reported negative correlation between bacterial blight development and antioxidant enzyme activity. Our studies indicated that PAL, POX, CAT, and TP play an important role in imparting resistance to downy mildew pathogen in snapmelon. Furthermore, measuring the activity of these antioxidant enzymes may be seen as an indicator 


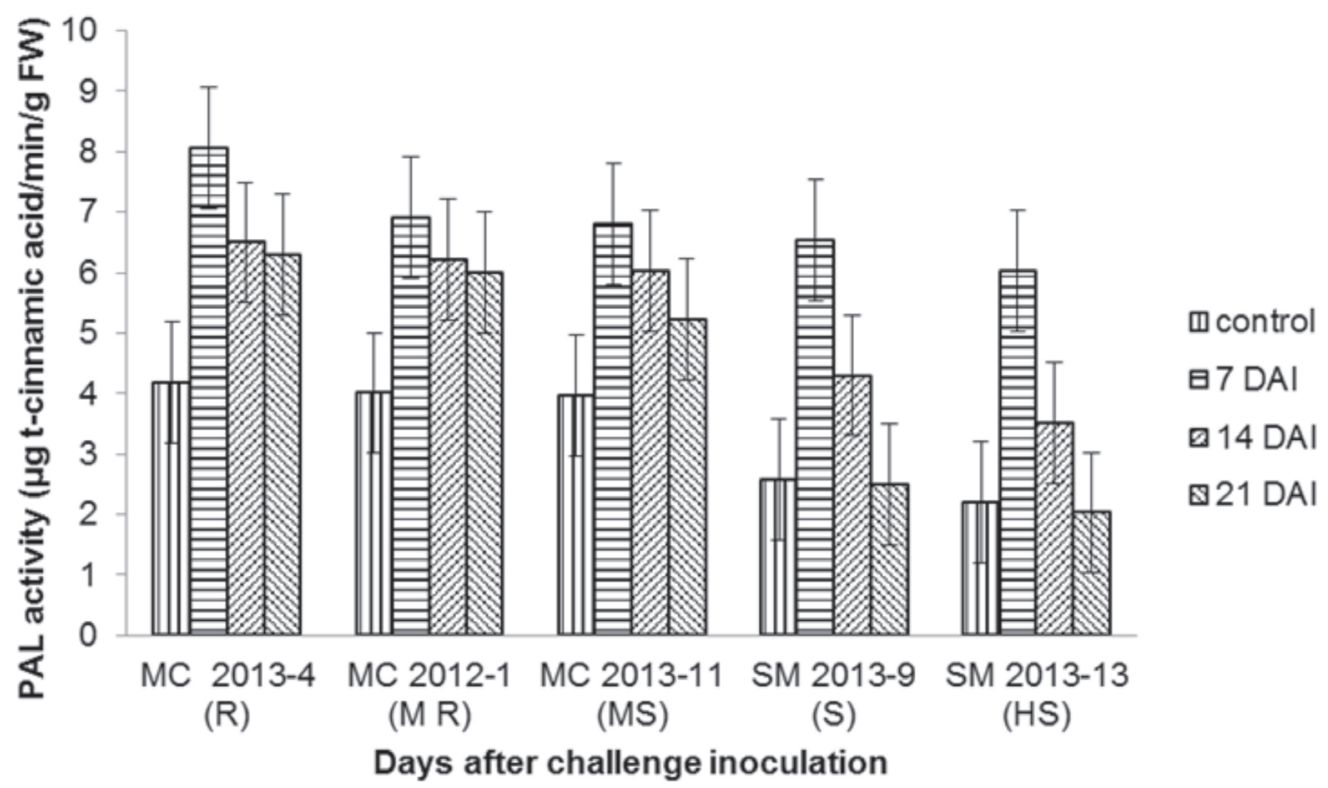

Fig. 3. Activity of PAL in snapmelon showing varied reaction pattern against $P$. cubensis at different days of challenge inoculation

Table 2. Activity of peroxidase, catalase, PAL and total phenols in snapmelon accessions showing varied reaction against $P$. cubensis at different time intervals $(7,14$ and 21 days after pathogen inoculation)

\begin{tabular}{lccccc}
\hline Accessions & $\begin{array}{c}\text { Disease } \\
\text { reaction }\end{array}$ & $\begin{array}{c}\text { Mean } \\
\text { peroxidase } \\
\text { activity } \\
(\Delta \mathrm{A} / \mathrm{min} / \mathrm{g} \mathrm{FW}) \\
\text { min/g FW })\end{array}$ & $\begin{array}{c}\text { Mean } \\
\text { catalase } \\
\text { activity } \\
\left(\mu \text { mole } \mathrm{H}_{2} \mathrm{O}_{2} /\right.\end{array}$ & $\begin{array}{c}\text { Mean PAL } \\
\text { activity } \\
(\mu \mathrm{g} \text { of t-cinnamic } \\
\text { acid/min/g FW })\end{array}$ & $\begin{array}{c}\text { Mean total } \\
\text { phenols } \\
(\mathrm{AA} / \mathrm{min} / \mathrm{g} \mathrm{DW})\end{array}$ \\
\hline MC 2013-4 & $\mathrm{R}$ & 18.96 & 163.21 & 6.95 & 1.44 \\
MC 2012-1 & $\mathrm{M} \mathrm{R}$ & 15.72 & 152.55 & 6.38 & 0.86 \\
MC 2013-11 & $\mathrm{MS}$ & 11.35 & 139.55 & 6.01 & 0.24 \\
SM 2013-9 & $\mathrm{S}$ & 8.40 & 80.98 & 4.44 & 0.15 \\
SM 2013-13 & $\mathrm{HS}$ & 6.33 & 69.55 & 3.85 & 0.10 \\
CD (5\%) & & 4.19 & 19.71 & 0.36 & 0.32 \\
\hline
\end{tabular}

Table 3. Correlation between disease severity at 21 days and enzyme activity during 7 days of pathogen inoculation in accessions $\mathrm{MC}$ 2013-4, MC 2012-1, MC2013-11, SM2013-9 and SM2013-13

\begin{tabular}{lccccr}
\hline Correlation & 21 days & POX & CAT & PAL & TP \\
\hline 21 days & & 0.345 & 0.193 & 0.196 & 0.592 \\
POX & -0.542 & & 0.009 & 0.037 & 0.018 \\
CAT & -0.693 & 0.962 & & 0.051 & 0.087 \\
PAL & -0.692 & 0.901 & 0.876 & & 0.043 \\
TP & -0.327 & 0.938 & 0.823 & 0.889 & \\
\hline
\end{tabular}

Critical Value of $r(p=0.05)=0.878$

$\mathrm{POX}=$ Peroxidase CAT $=$ Catalases $; \mathrm{PAL}=$ Phenylalahine ammonia lyase $; \mathrm{TP}=$ Total phenols

of genetic resistance against downy mildew. Kumar (2015) also reported negative correlation between enzyme activity and disease development in which he observed that lines of maize that were resistant to Dickeya zeae also showed highest antioxidant enzyme activity. Similarly, Dhkal et al. (2016) also reported high negative correlation between activity of antioxidant enzymes and development of disease in bacterial leaf streak in maize.

\section{REFERENCES}

Aebi HE (ed). (1983). Catalase. In: Bergmeyer HO Methods of Enzymatic Analysis III. pp. 273-80. Academic Press, New York. 
Balmer D, Planchamp C and Mauch-Mani B (2013). On the move: induced resistance in monocots. J. Exp. Bot. 64: 1249-1261.

Burrell MM and Rees TA (1974). Metabolism of phenylalanine and tyrosine in rice leaves infected by Pyricularia oryzae. Physiol. Plant. Pathol. 4: 497-508.

Chaman ME, Copaja SV and Argandona VH (2003). Relationships between salicylic acid content, phenylalanine ammonia-lyase (PAL) activity, and resistance of barley to aphid infestation. J. Agri. Food Chem. 51: 2227-2231.

Clariborne S and Fridovich I (ed). (1979). Assay for Peroxidase. In: Sadasivan and Manickam Biochemical method. pp 190. New Age International Publisher, New Delhi.

Dhkal M, Hunjan MS, Kaur H and Kaur R (2016). Biochemical basis of bacterial leaf streak resistance in maize. In: Phenotypic diversity in Acidovorax avenae subsp. avenae causing bacterial leaf streak of maize. Indian. Phytopath. 69: 373-380.

Gupta GK (2001). Downy mildew induced alterations in amino acids, proline and phenols in pearl millet. Indian J. Plant Pathol. 19: 87-93.

Jabeen N, Ahmed N, Ghani MY and Sofi PA (2009). Role of phenolic compounds in resistance to chilli wilt. Commun. Biometry Crop Sci. 4: 52-61.

Katoch R, Mann APS and Sohal BS (2005). Enhanced enzyme activities and induction of acquired resistance in pea with elicitors. J. Veg. Sci. 11: 67-83.

Kozik EU and Paris HS (2016). Proceedings of Cucurbitaceae 2016. In: the XI th EUCARPIA Meeting on Genetics and Breeding of Cucurbitaceae. pp 347-50. Eucarpia Warsaw, Poland.

Kumar A, Hunjan MS, Kaur H and Singh PP (2015). Characterization of Dickeya zeae isolates causing stalk rot of maize based on biochemical assays and antibiotic sensitivity. Indian Phytopath. 68: 375-379.

Lebeda A and Cohen Y (2011). Cucurbit downy mildew (Pseudoperonospora cubensis) - biology, ecology, epidemiology, host-pathogen interaction and control. Eur. J. Plant Path. 129: 157-92.
MacDonald MJ and D'Cunha GB (2007). A modern view of phenylalanine ammonia lyase. Biochem. Cell Biol. 85: 273282.

Olczak-Woltman H, Marcinkowska J and Niemirowicz- Szczytt $\mathrm{K}$ (2011). The genetic basis of resistance to downy mildew in Cucumis spp., latest developments and prospects. J. Appl. Genet. 52: 249-255.

Raju S, Jayalakshmi SK and Sreeramulu K (2008). Comparative study on the induction of defense related enzymes in two different cultivars of chickpea (Cicer arietinum) genotypes by salicylic acid, spermine and Fusarium oxysporum f. sp. ciceri. Aust. J. Crop Sci. 2: 121-140.

Reuveni R, Shimoni M, Karchi Z and Kuc J (1992). Peroxidase activity as a biochemical marker for resistance of Muskmelon (Cucumis melo) to Pseudoperonospora cubensis. Phytopathology 82: 749-753.

Roy A, Bal SS, Fergany M, Kaur S, Singh H, Malik AA, Singh J, Monforte AJ and Dhillon NPS (2011). Wild melon diversity in India (Punjab State). Genet. Resour. Crop Evol. 59: 755767.

Sharma N, Kaur C, Singh J and Gupta AK (2012) Biochemical responses associated with bacterial blight of rice (Oryza sativa). Arch. Phytopath. Pl. Protect. 45: 47-61.

Swain T and Hillis WE (1959). The Phenolic constituents of Prunus domestica. The qualitative analysis of Phenolic constituents. J. Sci. Food Agric. 10: 533-537.

Taheri $\mathrm{P}$ and Tarighi S (2012). The role of pathogenesis related proteins in the tomato-Rhizoctonia solani interaction. $J$. Botany. DOI: 10.1155/2012/137037.

Thind TS, Mohan C, Sokhi SS and Bedi JS (1989). A detached leaf technique for maintenance and multiplication of $P$. infestans and evaluation of fungicides. Curr. Sci. 58: 388389.

Vashisht VK, Thind TS and Lal T (2012). Introgression of wilt resistance from snapmelon into muskmelon. In: National Seminar on New Frontiers and Future Challenges in Horticultural Crops. Pp. 135. Punjab Agricultural University, Ludhiana, India.

Willekens H, Inze D, Van Montagu M and Van Camp W (1995). Catalase in Plants. Mol. Breed. 1: 207-228. 